Convention on the Elimination of All Forms of Discrimination against Women
Distr.: General

28 August 2012

Original: English

\title{
Committee on the Elimination of Discrimination
}

against Women

Fifty-second session

9-27 July 2012

Communication No. 32/2011

Views adopted by the Committee at its fifty-second session,

9-27 July 2012

Submitted by:

Alleged victims:

State party:

Date of communication:

References:

Date of adoption of views:
Isatou Jallow (represented by counsel, Albena Koycheva)

The author and her minor daughter

Bulgaria

15 November 2010 (initial submission)

Transmitted to the State party on 5 May 2011 (not issued in document form)

23 July 2012 


\section{Annex}

\section{Views of the Committee on the Elimination of Discrimination against Women under the Optional Protocol to the Convention on the Elimination of All Forms of Discrimination against Women}

\section{Communication No. 32/2011, Isatou Jallow v. Bulgaria}

Submitted by:

Alleged victims:

State party:

Date of communication:

References:
Isatou Jallow (represented by counsel, Albena Koycheva)

The author and her minor daughter

Bulgaria

15 November 2010 (initial submission)

Transmitted to the State party on 5 May 2011 (not issued in document form)

The Committee on the Elimination of Discrimination against Women, established under article 17 of the Convention on the Elimination of All Forms of Discrimination against Women,

Meeting on 23 July 2012,

Adopts the following:

Views under article 7, paragraph 3, of the Optional Protocol

1. The author of the communication is Ms. Isatou Jallow, a Gambian citizen born on 4 July 1982. She submits the communication on her behalf and on that of her daughter M.A.P., a Gambian and Bulgarian national, born on 28 October 2007. ${ }^{1}$ She claims that she and her daughter are victims of violations by Bulgaria of their rights under articles 1, 2, 3, 5 and 16, paragraphs 1 (c), (d), (f) and (g), of the Convention on the Elimination of All Forms of Discrimination against Women. The Convention and its Optional Protocol entered into force for Bulgaria on 8 May 1982 and 20 December 2006, respectively. The author is represented by counsel, Ms. Albena Koycheva.

\section{Facts as presented by the author}

2.1 The author previously lived in the Gambia. She is an illiterate woman with no education who can speak only her native language and English at an average level. In 2006, she met Mr. A.P., a Bulgarian national, who was doing business in the Gambia. In January 2007, he returned to the Gambia. On 23 February 2007, when she was already pregnant, they got married. Her husband then returned to Bulgaria, leaving her alone with no means of subsistence. She gave birth on 28 October 2007. After visiting the Gambia in the spring of 2008, and notwithstanding his initial reluctance to recognize the child as his, her husband declared on 10 June and

\footnotetext{
${ }^{1}$ Her daughter was born in Serrekunda, the Gambia. Bulgarian birth certificate No. 0494 was issued on 10 June 2008.
} 
21 August 2008, respectively, the birth of their daughter and their marriage, so that they could be registered in the official population register of Bulgaria. On 28 September 2008, the author and her daughter arrived in Bulgaria and began living with her husband in Sofia.

2.2 From her arrival in Bulgaria, the author experienced problems with her husband, who was aggressive, often under the influence of alcohol. He attempted to force her to take part in pornographic films and photographs, which she refused. He kept all her documents with him and began subjecting her to psychological and physical violence, including sexual abuse. She was not allowed to leave the house without her husband's permission or to seek employment. He constantly told her that her stay in Bulgaria depended on him and threatened that, if she resisted, he could have her imprisoned, confined to a mental institution or deported to the Gambia, without her daughter. He also made harsh comments about her physical appearance, black skin and illiteracy. He began abusing their daughter and kept pornographic photographs all over the apartment. He would masturbate in front of her and their daughter and watch pornographic films at home in their presence. $\mathrm{He}$ also taught their daughter to touch his penis.

2.3 In November 2008, the husband called the Child Protection Department and requested the authorities to convince the author to stop breastfeeding their daughter. He had previously often insisted that he wanted her to feed their daughter with ordinary food and to stop breastfeeding in order for her to lose weight. ${ }^{2}$ When social workers from the Department visited the home, they saw pornographic photographs and learned of her husband's domestic violence, causing them to call the police. Police officers came immediately, seized the pictures and informed the Sofia Regional Prosecutor's Office. They also advised the author to take her daughter and stay away from her husband, but provided no guidance about where to go, her vulnerable situation notwithstanding. No specific measure was taken to protect her and her daughter from domestic violence. The author therefore decided to take her daughter and seek shelter at the premises of a non-governmental organization, Animus Association, where they were sheltered from 7 to 9 November 2008. ${ }^{3}$ Subsequently, they were accommodated at a mother and child municipal shelter from 10 to 15 November 2008. Her husband, however, found them and convinced her to return to the apartment. ${ }^{4}$

2.4 On 30 March 2009, the Sofia Regional Prosecutor's Office refused to continue with a pretrial investigation into the husband's alleged offence because the evidence collected was insufficient to presume the existence of an offence. The Office concluded that the seized photographs did not constitute an offence insomuch as they were part of the husband's own private collection and taken with the consent of the pictured women, who were adults. The decision was based on the information provided by the police and the social services. The author was never questioned.

2 According to the husband's submission to the Sofia Regional Court dated 29 July 2009, after the author's refusal to give the baby ordinary food, he requested the authorities to explain to the author that the child needed other forms of nutrition than breastfeeding.

3 According to the certificate issued by Animus Association, on 28 October 2008, the Child Protection Department requested the Association to provide shelter to the author and her daughter, who stayed at its centre from 7 to 11 November 2008.

4 According to the shelter's certificate, provided by the author, she and her daughter were sheltered from 10 to 17 November 2008, when she voluntarily decided to leave. 
2.5 On 5 June 2009 , the author was admitted to a crisis centre maintained by Animus Association. ${ }^{5} \mathrm{~A}$ few hours after her arrival, the crisis centre was telephoned by the director of a kindergarten, who reported that the husband had attempted to force the kindergarten to accept their daughter, saying that her mother had left her alone and escaped to the centre. The author took her daughter back with her to the centre. On 12 June 2009, the author and her daughter returned home. ${ }^{6}$ Police officers were called several times to stop domestic violence against the author. The evident risks to the author and her daughter notwithstanding, they limited themselves to orally warning her husband.

2.6 On 6 July 2009, 10 months after her arrival, the author received her Bulgarian residence permit. The situation escalated such that the author suggested to her husband that they should begin divorce proceedings. He refused, however, as he wished to maintain custody of their daughter.

2.7 On 27 July 2009, the husband filed an application with the Sofia Regional Court under the Protection against Domestic Violence Act, alleging that he was a victim of physiological and physical violence. He submitted that he and his daughter had been victims of domestic violence on several occasions, requesting the Court to grant an emergency protection order. On 28 July 2009, the Court refused the husband's application and gave him one month to file a detailed complaint, to provide specific information and witnesses or evidence concerning each violent event and to explain how those events had affected his daughter. On 29 July 2009, the husband filed a new application, in which he alleged that the author had attacked and insulted him and his daughter on 3, 4, 5, 6 and 20 November and on 26 December 2008, and on 25, 26 and 27 July 2009. He accused the author of having on one occasion attempted to use a knife. Furthermore, he reported that she would slap their daughter across the face, even in front of others. He also accused the author of having fought with people in the neighbourhood and having threatened to kill his mother and their daughter and to commit suicide. He attached to the application a medical certificate dated 24 November 2008 describing personal injuries that had caused him pain and suffering. He also attached a picture showing the back of an injured child. According to the author, the girl in the picture was evidently much older than her 2-year-old daughter. The husband requested that the Court should grant a protection order to forbid the author from coming close to him or their daughter and to force her to be admitted to a mental hospital.

2.8 On 29 July 2009, the Sofia Regional Court, on the basis of the evidence presented by the husband, issued an emergency protection order pursuant to section 5 of the Protection against Domestic Violence Act. Among other measures, the Court ordered the removal of the author from the family home, a ban on her being near the home and the temporary relocation of their daughter with the husband. It considered that the application showed the existence of a direct and imminent threat to the life and health of the husband and their daughter. The emergency protection order was issued on the basis of the husband's statement

5 The author argues that her husband left her there, against her will. According to her submission to the Sofia Regional Court dated 14 September 2009, however, in June 2009, at her husband's insistence, the author voluntarily accepted to go to the centre and left him with their daughter to give him the opportunity to realize how demanding childcare was.

6 According to the certificate issued by Animus Association dated 19 August 2009, the author left the centre at her husband's insistence. 
alone. ${ }^{7}$ The police executed the protection order and notified the author about the application and future court hearings. No translation of the order was provided, however. According to the author, the order was unappealable and was valid until the court proceedings under the Protection against Domestic Violence Act were completed. ${ }^{8}$

2.9 On 21 August 2009, the author learned that the husband had removed their daughter from their home. She contacted the police, the State Agency for Child Protection and the Sofia Regional Prosecutor's Office to enquire about her daughter, stressing that a child of her daughter's age needed to be near her mother. The police refused the author's request, aware of the emergency protection order, saying that her husband was not obliged to inform her about the whereabouts of her daughter, whom he could send elsewhere or designate another person to look after. The police also refused to assist her to take her personal belongings from the family home. On 27 August 2009, she submitted a request for information about her daughter to the Sofia Regional Prosecutor's Office and to the State Agency for Child Protection. The former never replied to her request and the latter forwarded her complaint to the local Child Protection Department, which informed her only that her daughter was well under her father's care. For several months, these institutions neither took action nor informed the author about the conditions in which her daughter lived. ${ }^{9}$

2.10 On 7 September 2009 , the judge adjourned the initial hearing owing to an irregular notification and the absence of an interpreter. On 16 and 18 September and 15 October 2009, hearings took place in the presence of the author, her counsel, a representative of the social services and an interpreter. At the first hearing, the author requested the lifting of the emergency protection order that had separated her from her daughter. She denied the allegations against her, claiming that the order lacked evidence and did not meet the requirements laid down in the Protection against Domestic Violence Act. She claimed that, in her vulnerable condition, she and her daughter had been victims of psychological and physical violence by her husband. She had not previously lodged a complaint against him because she did not know the law. The author also submits that the social report prepared by the Child Protection Department on the parental capacity of the father, which had been provided to the Court, made no mention of the incidents of domestic violence and the husband's pornographic material. Furthermore, it failed to analyse the author's

7 According to section 13 (3) of the Protection against Domestic Violence Act, where no other evidence exists, the court shall issue a protection order solely based on the statement by virtue of section 9 (3), which provides that a statement by the applicant concerning the violence applied shall also be enclosed to the application under section 8 , point 1 , which notes that the proceedings for issuing an order may be instituted on the application of the victim.

8 According to section 19 of the Protection against Domestic Violence Act, an emergency protection order shall have effect until a protection order is issued or until the court refuses the application or request.

9 From the information available in the case file provided by the author, it appears that, according to a report by the State Agency for Child Protection, the author's lawyer was informed on 10 September 2009 that the State Agency had requested the police to answer and investigate the author's request for information about her child's whereabouts and condition. In addition, on 1 September 2009, the husband informed the Sofia Regional Court that he had decided to move his daughter for her safety to the home of a close friend, who lived in the municipality of Kostenets, where he would spend the weekends. He further noted that neither the municipality nor non governmental organizations could offer quick access to a kindergarten for the child. 
parental capacity as mother of the child and the effect that her absence might have on her daughter's life.

2.11 On 23 December 2009, the Sofia Regional Court dismissed the husband's application and his request for a permanent protection order for lack of evidence. The medical certificate dated 24 November 2008 offered by the husband was rejected pursuant to section 10 of the Protection against Domestic Violence Act, which states that a request should be filed within one month of the date on which the act of domestic violence occurred. Since the husband appealed against the Court's decision, however, the emergency protection order against the author continued to apply. ${ }^{10}$ When the author continued her efforts to see and take care of her daughter, she was informed by the State Agency for Child Protection that the father was taking sufficient care of their daughter. ${ }^{11}$

2.12 In the third quarter of 2009 , the husband initiated divorce proceedings before the Sofia Regional Court, seeking custody of their daughter.

2.13 On 25 January 2010 , the author filed a request for interim measures regarding the custody of her daughter within the divorce proceedings. She informed the Court that, while she agreed to divorce, she disagreed with the grounds adduced by her husband. On 14 February 2010, her husband and daughter visited her. Her husband behaved aggressively and was under the influence of alcohol. He made a scene, shouting at her and beating her several times in front of their daughter, who was crying. No one was around to help her. The author consulted a doctor, but could not pay the cost of a medical certificate attesting to the physical violence.

2.14 On 15 March 2010, the Sofia Regional Court held a divorce hearing. The Court received a new social report from the Child Protection Department that included broader information about the child and the parental capacity of the two parents. The child's interests were considered with utmost attention and a social worker from the Department was present. After listening to the parties and the social worker, the judge strongly advised the parties and their counsel to endeavour to reach an agreement. Two hours after the completion of the hearing, the author was visited by immigration officials to verify her address and employment.

10 According to section 17 (2) of the Protection against Domestic Violence Act, the appeal should not stay the execution of the judgement.

11 On 20 January 2010, the author submitted a new request for information to the Agency. On 1 February 2010, the Agency informed the author that social workers periodically checked the child's condition and had assisted the father to enrol the child in a kindergarten. The child had a family doctor and no sickness had been recorded. The apartment where the child lived appeared clean, with a correct atmosphere. She had begun speaking some words, in Bulgarian. The father had his mother's help to take care of the child, who showed no sign of being subjected to violence. In addition, the author was informed that she could request more information from the district office of the Child Protection Department, but should be accompanied by an interpreter. The Agency also wrote to the Department, requesting it to follow up on the case and to assist the author with information. On 15 February 2010, the district office of the Child Protection Department wrote to the author, noting that it had been unable to transmit to her any information previously because it had not had her address. The letter confirmed the information provided by the Agency. The child had spent a period outside Sofia at the home of her husband's friends. Her husband had stayed with them during weekends and decided to move the child back to Sofia before the winter. On 7 December 2009, he had sought help to enrol the child in a kindergarten. She was also informed that the husband was not against her visiting the child, if such visits were regulated. Lastly, she was invited to visit the district office of the Child Protection Department, accompanied by an interpreter. 
2.15 The authorities' failure to provide her and her daughter with effective protection and the harassment and violence that she underwent notwithstanding, the author felt compelled to agree to a divorce (by mutual agreement) because she thought that it was the only way to regain custody of her daughter. She accepted almost all the unfavourable conditions that her husband imposed on her. ${ }^{12}$ On 22 March 2010, the Court approved the divorce and custody agreement, with custody awarded to the mother. ${ }^{13}$

2.16 The author states that she has exhausted all available domestic remedies.

\section{Complaint}

3.1 The author claims that articles 1, 2, 3, 5 and 16, paragraphs 1 (c), (d), (f) and $(\mathrm{g})$, of the Convention were violated by the State party as a result of the discriminatory treatment that she and her daughter, as women, received from its authorities, and its failure to protect them from domestic gender-based violence and to sanction the perpetrator.

3.2 The author argues that the State party's failure to prevent domestic violence affects women more than men, in violation of article 1 of the Convention. She claims that the State party does not consider domestic violence to be a real and serious threat. Its legislation and the practice of its public institutions, including the judicial system, do not recognize gender-based violence. For example, the Protection against Domestic Violence Act contains no special protective measure for women or mothers, even though the prevailing majority of applicants are women and their children and the perpetrators men.

3.3 As to the alleged violations of article 2, it is argued that the State party has taken no measures to introduce legal provisions governing violence against women, in particular psychological violence. In addition, judicial practice and procedural rules do not clearly recognize this form of violence. The Protection against Domestic Violence Act and the Child Protection Act are gender neutral, although the most affected are women and girls abused by men. Within domestic violence proceedings, the legal requirement to show a direct and immediate danger to the applicant's life is arbitrarily considered by judges, given that they base their decision on the applicant's statement. Judges are not authorized to revise an emergency protection order when new evidence is collected and/or the respondent is heard in court. ${ }^{14}$ The courts are obliged to complete the case in one hearing and to announce the final decision to the parties immediately. The State party has thus failed to implement its obligations pursuant to paragraphs (f) and (g) of article 2.

3.4 The author argues that the exercise and enjoyment of her and her daughter's rights were affected by the State party's failure to take appropriate measures, in violation of article 3 of the Convention. She had no or limited access to the

12 The case file contains no further details or documentation on the alleged unfavourable conditions that her husband imposed in order to obtain a divorce.

13 According to the Court decision, the father had the right to contact the child each first and third weekend, from 10 a.m. on the Saturday to 6 p.m. on the Sunday. During the summer, he had the right to spend one month with the child. He should also pay 50 euros as a monthly allowance for the child.

14 According to section 17 (2) of the Protection against Domestic Violence Act, the appeal should not stay the execution of the judgement. While the Act contains no provision with regard to this affirmation, the author maintains that, in practice, the courts handle cases in this manner. 
institutions dealing with issues relating to gender-based violence (the police, the courts, the health-care system and the State Agency for Child Protection) because her lack of knowledge of Bulgarian prevented her from addressing those institutions directly unless she secured an interpreter at her own expense. She could not have access to the forensic medical services because victims of domestic violence are not entitled to free medical care and forensic medical certificates, nor to legal aid. All this disproportionately affects women, in particular those with low social status and income, who are dependent on their partners even though those partners are often the offenders. The State party also failed to take appropriate measures to protect women, especially mothers, from domestic violence. The law and the practice of the authorities do not recognize many forms of violence against women, resulting in inequality with men and lack of protection of motherhood. There is no effective support for victims. The author's requests notwithstanding, the State Agency for Child Protection never questioned the forced separation of mother and daughter. It is further argued that women victims often do not seek protection from public institutions, in part because of the stigma that may mark them and the general negative reaction of society, and, when they do do so, often the authorities offer no adequate protection. When the victim requests a criminal investigation, the general response by the prosecutors is that the victim should address a civil court and seek protection under the Protection against Domestic Violence Act. The State party has also failed to provide training to law enforcement and judicial staff about domestic violence against women, in particular mothers.

3.5 Regarding the alleged violation of article 5, it is submitted that the authorities are firmly convinced that equality between women and men has been already achieved. In public discussions, some concerns have been expressed about the possible misuse of the Protection against Domestic Violence Act by women against men, but never the reverse. Judicial proceedings regarding child custody usually take more than one year. There is no effective mechanism to monitor the child's condition and the care given by the parent or parents. A formalistic reading of the regulations on the equality of parents' rights prevails over other notions, such as the best interests of the child. In this framework, maternity as a social function is neglected.

3.6 It is also claimed that the State party contravened its obligations enshrined in article 16, paragraphs 1 (c), (d), (f) and (g), of the Convention. While married, the author was separated from her daughter and deprived of any information about her. Her requests notwithstanding, various public institutions did not consider her extreme vulnerability and the real risk of losing her connection with her daughter. Similarly, these institutions refused to protect her and to assist her to contact her daughter, even when she warned that her daughter might be subjected to sexual abuse by her father. Furthermore, the authorities' social reports submitted as part of the judicial proceedings under the Protection against Domestic Violence Act contained only the information provided by the father and did not consider those elements and the fact that the author was kept under her husband's full control. Her rights as a wife and mother therefore went unrecognized and unprotected, putting the author in a situation in which she had to accept all the conditions imposed by her husband in order to obtain a divorce and to regain custody of her daughter.

3.7 With regard to the remedy, the author requests fair compensation, appropriate child support and legal assistance, in addition to reparation proportionate to the physical and mental harm caused to her and her daughter and to the gravity of the 
violation of their rights. Furthermore, the author requests effective measures to guarantee their security.

3.8 The author also requests that the State party take specific measures to change the law and practice in the State party in order for there to be effective protection for women victims of gender-based violence. These measures include training of judges and authorities in general and free legal aid and translation services for victims.

\section{State party's submissions on admissibility and the merits}

4.1 On 11 July 2011, the State party challenged the admissibility of the communication. It stated that the author's allegations were ill founded and that the application before a court pursuant to the Protection against Domestic Violence Act was a special procedure that did not exclude other civil, administrative and criminal proceedings that might determine the responsibility of the alleged perpetrator.

4.2 The State party contends that it has taken adequate measures to implement its obligations under the Convention and other fundamental legal instruments on discrimination, notably the European Union rules and standards. Equality between men and women is a constitutional principle and forms the basis of the functioning of social and political life. This includes equal rights during marriage and with regard to the custody of children. Institutional mechanisms, such as the Commis sion for Protection against Discrimination and the State Agency for Child Protection, were established as part of the implementation of these international obligations.

4.3 The authorities of the Ministry of the Interior that dealt with the author's case acted within their respective competences and without any discriminatory attitude. The author received all the necessary assistance from the police pursuant to the Protection against Domestic Violence Act.

4.4 On 7 November 2011, the State party submitted its observations on the admissibility and the merits of the communication. As to the exhaustion of domestic remedies, it reiterates that different means for protection against domestic violence and discrimination are available and regulated by the Penal Code, the Protection against Domestic Violence Act and the Protection against Discrimination Act, among other legislation. The author, as a victim of discrimination on the grounds of gender, could also have submitted a complaint to the Commission for Protection against Discrimination pursuant to the Protection against Discrimination Act. Victims are also entitled to seek special anti-discrimination court action to ensure that discriminatory practices against them are discontinued and to receive compensation for such violations.

4.5 The State party states that it has continuous and targeted policies against domestic violence. In this framework, on 29 March 2005, it enacted the Protection against Domestic Violence Act, which defines domestic violence. ${ }^{15}$ Its protection is extended to a wide range of persons in various situations, including in terms of marriage, guardianship and child custody.

15 According to section 2 of the Protection against Domestic Violence Act, domestic violence is any act of physical, mental or sexual violence, and any attempted such violence, as well as the forcible restriction of individual freedom and of privacy, carried out against individuals who have or have had family or kinship ties or cohabit or dwell in the same home. 
4.6 Victims of domestic violence may seek protection under the Protection against Domestic Violence Act. The procedure is judicial-administrative in nature. It contains elements of criminal proceedings but remains under civil law, which makes it possible to shift the burden of proof in favour of the victims. A court can impose on the perpetrator measures for a period of one month to one year. Judgements should be rendered within one month. If the victim's life or health is at serious risk, an emergency protection order can be issued immediately (within 24 hours as part of ex parte court proceedings). Documents issued by organizations working to support victims of domestic violence are admissible.

4.7 In addition to the special protection under the Protection against Domestic Violence Act, the Penal Code also provides protection to victims of domestic violence if that violence may constitute a criminal offence or offences. Specific provision is made in many cases for circumstances in which the victim is the spouse of the perpetrator, and the close relationship between the victim and the perpetrator can be considered an aggravating circumstance. Pursuant to article 152, paragraph 1, of the Penal Code, sexual intercourse against the will of the woman remains an offence even if the perpetrator and the victim are married or in a de facto conjugal cohabitation.

4.8 The State party, together with relevant non-governmental organizations and the media, carries out public campaigns and initiatives to raise awareness of domestic violence. Such activities are part of a national programme to prevent and protect against domestic violence, which is adopted annually. In addition, on the basis of agreements between the Ministry of the Interior and non-governmental organizations, many joint initiatives have been implemented to strengthen efforts to prevent gender-based violence and human trafficking.

\section{Author's comments on the State party's observations on admissibility and the merits}

5.1 The author submitted her comments on the State party's observations on admissibility and the merits on 24 November 2011. She points out that the State party's observations do not refer to the facts of the case and therefore neither challenge her allegations nor provide evidence against them. She also submits the final judgement by the Sofia City Court of 14 March 2011, in which the Court dismissed her husband's appeal and declared the judgement from the Sofia Regional Court of 23 December 2009 effective and final.

5.2 The author states that the State party failed to identify the legal guarantees of special protection for mothers and children in the event of domestic violence and how they would protect motherhood. She reiterates her previous allegations as to the gender-neutral feature of the Protection against Domestic Violence Act and points out that, since she did not speak Bulgarian, in practice she had no access to a court.

5.3 Judges and law enforcement personnel are not trained to identify and respond urgently to the gender-based nature of domestic violence. In the present case, the judge of the Sofia Regional Court was incapable of assessing adequately her husband's application for a protection order and the consequence of that order on her daughter. During the period in which the author and her daughter were separated, she sought help from many authorities, but received the stereotypical answer that the father enjoyed equal rights as a parent. Moreover, the judge never considered the allegations of violence submitted by the author, even after receiving written evidence of the husband's criminal record. 
5.4 The author challenges the State party's allegation that she did not exhaust domestic remedies. The court proceedings and the emergency protection order were of a longer duration than established by law. The court of first instance should have heard the matter within one month, yet the proceedings actually lasted five months. The court of second instance was supposed to hold hearings within 14 days. By the time of the author's submission to the Committee (after 14 months), the case remained pending, meaning that the remedy has been unreasonably prolonged. As other proceedings do not protect the victim against domestic violence and, within them, the author could not request protection for her daughter, they do not provide an effective remedy.

5.5 On 5 January 2012, the author transmitted additional comments to the Committee. She submits that no legislation mentioned by the State party, including the Protection against Domestic Violence Act, contains provisions on the effective protection of victims of domestic violence who are dependent on the perpetrator.

5.6 She claims that the authorities failed to protect her under the Child Protection Act. On several occasions, the author sought help from the State Agency for Child Protection to find out where the father had hidden the daughter. Given that the authorities were aware that the author and her daughter were subject to domestic violence, in a vulnerable position and depended on the aggressor, they failed to act with due diligence in providing the maximum effective protection of the law. The Director of the Social Assistance Directorate was entitled to initiate proceedings to issue a protection order pursuant to the Protection against Domestic Violence Act, but did not do so. ${ }^{16}$ Consequently, the father's parental rights were accorded highest priority by the State party's authorities, regardless of the harmful effect on the author and her daughter.

5.7 The author notes that, while the State party's observations stress that the husband had also made complaints against the author, they do not consider the outcome of these complaints and their main and final purpose. This illustrates that the authorities are much more inclined to trust a husband or father than a wife or mother. In the present case, the Sofia Regional Court was not in a position to assess who needed to be protected from domestic violence and therefore to issue the emergency protection order requested by her husband.

5.8 The State party shows its strong stereotypes in relation to domestic violence as a gender-neutral issue, and ignores the fact that it disproportionately affects women, in most cases mothers. Consequently, the law is applied in a way that purports to be equal for men and women, regardless of its obvious inadequate effects. ${ }^{17}$

\section{State party's further submission on admissibility}

6.1 By further submission of 27 January 2012, the State party reiterates that the communication is inadmissible on the ground of non-exhaustion of domestic remedies pursuant to article 4, paragraph 1, of the Optional Protocol, stating that there is no record of any request to review any circumstances alleging domestic

16 According to section 8 (2) of the Protection against Domestic Violence Act, the proceeding for issuing an order may be instituted at the request of the Director of the Social Assistance Directorate.

17 The author refers to the Committee's general recommendations No. 19, para. 11, and No. 28, para. 37. 
violence or gender discrimination submitted by the author. It points out the Bulgarian judicial system can offer clear and effective protection in cases of domestic violence.

6.2 It reiterates that various initiatives have been launched to raise awareness of domestic violence and protection procedures. The social services offer support, including crisis centres and mother and baby units, to women and their children who are victims of violence. They provide various kinds of support, including social, psychological and legal counselling, to victims of violence for six months and temporary accommodation for up to six months to pregnant women and mothers at risk of abandoning their children.

6.3 The Constitution and legislation protect the rights of foreign residents. In April 2010, the Penal Procedure Code was amended to guarantee that any accused person without a command of Bulgarian would have access to the necessary assistance. The State party has launched various initiatives to provide information about the right to legal aid in foreign languages. It is further asserted that the author did not contact the State Agency for Refugees and the Migration Directorate of the Ministry of the Interior, which deal with migration issues.

\section{Issues and proceedings before the Committee concerning admissibility}

7.1 Pursuant to rule 72, paragraph 4, of its rules of procedure, the Committee shall consider the applicability of the admissibility grounds referred to in articles 2, 3 and 4 of the Optional Protocol before considering the merits of the communication.

7.2 In accordance with article 4, paragraph 2, of the Optional Protocol, the Committee is satisfied that the same matter has not been nor is being examined under another procedure of international investigation or settlement.

7.3 The Committee notes the State party's argument that the author has failed to exhaust domestic remedies since the proceedings to seek protection from domestic violence pursuant to the Protection against Domestic Violence Act do not prevent the author from lodging a civil, criminal or administrative application or complaint within the framework of other proceedings regulated by the Penal Code and the Protection against Discrimination Act. The Committee also notes the author's claims that the court proceedings under the Protection against Domestic Violence Act were unreasonably prolonged and that other proceedings mentioned by the State party are not aimed at protecting victims against domestic violence. The Committee further notes the author's argument that she had no other effective remedy available as other proceedings do not protect victims against domestic violence and that she could not request specific protection for her daughter.

7.4 The Committee notes that, on at least one occasion, on the advice of the police, the author stayed at a shelter for victims of domestic violence. It further notes that, on several occasions, the author contacted the police, the Child Protection Department and the Sofia Regional Prosecutor's Office to obtain information on her daughter's whereabouts and well-being and to protect her daughter's interests. The Committee observes that the authorities took no measures to address her concerns and that, on the contrary, on 30 March 2009, the Sofia Regional Prosecutor's Office discontinued the preliminary investigation into her husband's alleged offence, without hearing the author. 
7.5 The Committee observes that the Sofia Regional Court granted the husband's application for an emergency protection order on 29 July 2009 and that this included a separation of the author from her daughter without the possibility of appeal. The Committee further notes that, while the husband's application for a permanent protection order under the Protection against Domestic Violence Act was rejected on 23 December 2009, the emergency protection order that imposed a separation of the author from her daughter remained valid during the appeal proceedings initiated by the husband under the Act. The final decision remained pending at the time of submission of the author's communication, almost 14 months after the proceedings had begun, and was only finally decided on 14 March 2011, when the Sofia City Court dismissed her husband's appeal and declared the judgement of the Sofia Regional Court of 23 December 2009 effective and final. The Committee observes that, in the absence of any explanation by the State party as to the length of these appeal proceedings, the delay cannot be attributed to the author.

7.6 In the absence of any details of the remedies that the State party claimed would be available to the author in the circumstances of her case or of any sufficient explanation as to how these remedies would be effective in protecting the rights of the author and her daughter, and considering the authorities' failure to take measures to address the author's concerns with regard to reported domestic violence and concerns of child protection, the Committee finds that it would be unlikely that the remedies referred to by the State party would bring effective relief for the author and her daughter, and therefore concludes that article 4, paragraph 1, of the Optional Protocol does not preclude it from considering the communication.

7.7 The Committee notes that the State party maintains that the communication should be considered inadmissible because the author's claims are manifestly ill founded and not sufficiently substantiated. The Committee considers, however, that the author's allegations have been sufficiently substantiated for the purposes of admissibility in accordance with the requirements of article 4, paragraph 2 (c), of the Optional Protocol, and proceeds with their consideration on the merits.

\section{Consideration on the merits}

8.1 The Committee has considered the present communication in the light of all the information made available to it by the author and by the State party, as provided in article 7, paragraph 1, of the Optional Protocol.

8.2 The Committee takes note of the author's allegations that the State party did not provide her and her husband with the same protection from domestic violence. In contrast with her husband's application under the Protection against Domestic Violence Act that was duly heard, the State party's authorities failed to act with due diligence, to provide her with effective protection and to take into account her vulnerable position, as an illiterate migrant woman with a small daughter without a command of Bulgarian or relatives in the State party. It further notes that no translation of the emergency protection order was provided to the author. The Committee also takes note of the author's allegation that the unnecessary prolonged proceedings under the Protection against Domestic Violence Act, in particular the delays and the issuance of the permanent protection order, after the issuance of an emergency order without hearing both parties or the possibility of appealing against it, were discriminatory. It further notes the author's argument that judicial proceedings regarding child custody usually take more than one year and that there 
is no effective mechanism to monitor a child's condition in the care of the other parent. The Committee also notes that the author's averment that, because of the lack of effective protection, she felt obliged to agree to a divorce by mutual consent on disadvantageous terms in order to regain custody of her daughter.

8.3 The Committee takes note of the State party's observations that the authorities that dealt with the author's case acted within their competence and without any discriminatory attitude towards the author, providing her with the necessary assistance. It also takes note of the State party's assertion that its judicial system can offer clear and effective protection in cases of domestic violence and that various initiatives have been launched to raise awareness of domestic violence and protection procedures.

8.4 The Committee also observes that, in November 2008, when social workers from the Child Protection Department were called by her husband to convince the author to stop breastfeeding their daughter, the author informed them that she and her daughter had been subjected to psychological and physical violence by her husband. It notes that the police, having been called by the social workers, recommended that the author and her daughter should seek shelter protection, which they did from 7 to 15 November 2008. Although the police and the Prosecutor's Office had been informed by the social workers about the author's claims of domestic violence, they limited their investigation to the husband's pornographic pictures and failed to hear the author in the pre-investigation procedure. Moreover, the State party's authorities neither investigated nor instituted proceedings regarding the alleged domestic violence against the author and her daughter, notwithstanding the power of the Director of the Social Assistance Directorate to institute proceedings pursuant to section 8 of the Protection against Domestic Violence Act. ${ }^{18}$ The Committee recalls that its general recommendation No. 19 (1992) states that the definition of discrimination enshrined in article 1 of the Convention includes gender-based violence; that it is not restricted to action by or on behalf of Governments; and that States may also be responsible for private acts if they fail to act with due diligence to prevent violations of rights or to investigate and punish acts of violence. ${ }^{19}$ Furthermore, as established in general recommendation No. 28 (2010), States parties are obliged to react actively against discrimination against women. In the present case, the Committee considers that the author's allegations of domestic violence gathered by the social workers and transmitted to the police in November 2008 were not followed by a suitable and timely investigation, either at that moment or within the context of the domestic violence proceedings instituted by her husband. The Committee therefore concludes that the facts before it reveal a violation of the State party's obligations under article 2, paragraphs (d) and (e), read in conjunction with articles 1 and 3 , of the Convention.

8.5 The Committee observes that the husband's applications submitted to the Sofia Regional Court on 27 and 29 July 2009 led to the issuance of an emergency protection order on 29 July 2009 that forcibly separated the author and her daughter

18 Section 8 (2) of the Protection against Domestic Violence Act states that the proceeding for issuing an order may be instituted at the request of the Director of the Social Assistance Directorate.

19 See communication No. 5/2005, Sahide Goekce (deceased) v. Austria, views adopted on 6 August 2007; communication No. 6/2005, Fatma Yildirim (deceased) v. Austria, views adopted on 6 August 2007. 
until the Regional Court, in separate proceedings, approved the divorce agreement on 22 March 2010, which gave her custody of her daughter. The Committee notes that, in issuing the emergency protection order that included a temporary determination of the custody of the author's daughter, the Court relied on the husband's statement and did not consider or was not alerted by the competent authorities to the incidents of domestic violence reported by the author during the visit by social workers and her several requests for help from the police in order to protect herself and her daughter. The Committee also notes that the first-instance proceedings lasted almost five months and that, regardless of the author's request, the emergency protection order was not removed, even after the first-instance court had dismissed the husband's application for a permanent protection order. During this considerable period, the information provided to the author on the whereabouts and condition of her daughter was limited and she was unable to gather more information since interpreting services were unavailable to her. The Committee considers that the State party failed to provide a reasonable explanation as to why the emergency protection order was not removed after the Sofia Regional Court dismissed the husband's application for a permanent protection order on 23 December 2009 and as to why the appeal proceedings in the circumstances of the present case were prolonged. Considering that the author and her daughter were in a vulnerable position, in particular because the author is an illiterate migrant woman without a command of Bulgarian or relatives in the State party, and dependent on her husband, the Committee concludes that the State party failed to comply with its obligations established in article 2, paragraphs (b) and (c), read in conjunction with articles 1 and 3, of the Convention.

8.6 With regard to the author's allegation of a violation of article 5, paragraph (a), and article 16, paragraphs 1 (c), (d), (f) and (g), of the Convention, the Committee observes that it addressed those articles in its general recommendation No. 19 (1992) on violence against women. In its general recommendation No. 21, the Committee stressed that the provisions of general recommendation No. 19 had great significance for women's abilities to enjoy rights and freedoms on an equal basis with men. It has stated on many occasions that traditional attitudes by which women are regarded as subordinate to men contribute to violence against them. In respect of the case before the Committee, it notes that, in issuing the emergency protection order and taking other decisions, the State party's authorities relied on the husband's statement and actions, despite being aware of the author's vulnerable position and dependency on him. The Committee also observes that the authorities based their activities on a stereotyped notion that the husband was superior and that his opinions should be taken seriously, disregarding the fact that domestic violence proportionally affects women considerably more than men. The Committee also notes that the author was separated from her daughter for almost eight months, during which time she received no information on the care that her daughter was receiving and was granted no visitation rights. Under such circumstances, the Committee considers that both the author and her daughter are victims of genderbased discrimination because the State party failed to protect the author's equal rights in marriage and as a parent and to regard her daughter's interests as paramount. That the emergency protection order that separated the author from her daughter was issued without due consideration of earlier incidents of domestic violence and of the author's claim that she and her daughter were in fact the ones in need of protection against domestic violence, and that the emergency protection order was not removed by the Sofia Regional Court when a permanent protection 
order was rejected, lead the Committee to conclude that the State party failed to take all appropriate measures under article 5, paragraph (a), and article 16, paragraphs 1 (c), (d), and (f), of the Convention.

8.7 The Committee would like to recognize that the author and her daughter have suffered serious moral and pecuniary damage and prejudice. The author had to continue a relationship with a violent husband since she was in a vulnerable position and did not receive adequate protection. For a considerable period, the author and her daughter were forcibly separated. Furthermore, the Committee has taken note of the author's statement that she had to accept disadvantageous terms for a divorce by mutual consent in order to obtain custody of her daughter.

8.8 Acting under article 7, paragraph 3, of the Optional Protocol to the Convention, and in the light of the above considerations, the Committee is of the view that the State party has failed to fulfil its obligations and has thereby violated the rights of the author and her daughter under article 2, paragraphs (b), (c), (d), (e) and (f), article 5, paragraph (a), and article 16, paragraphs (c), (d) and (f), read in conjunction with articles 1 and 3 , of the Convention, and makes the following recommendations to the State party:

1. Concerning the author of the communication and her daughter:

To provide them with appropriate compensation commensurate with the gravity of the violations of their rights;

2. General:

(a) To take measures to ensure that women victims of domestic violence, in particular migrant women, have effective access to services related to protection against domestic violence and to justice, including interpretation or translation of documents, and that the manner in which domestic courts apply the law is consistent with the State party's obligations under the Convention;

(b) To take the legislative or other measures necessary to ensure that, in the determination of custody and visitation rights of children, incidents of violence are taken into account and that the rights and safety of the victim or children are not jeopardized;

(c) To provide for appropriate and regular training on the Convention, its Optional Protocol and its general recommendations for judges, prosecutors, the staff of the State Agency for Child Protection and law enforcement personnel in a gender-sensitive manner, having particular regard to multiple discrimination, so as to ensure that complaints regarding gender-based violence are received and considered adequately.

8.9 In accordance with article 7, paragraph 4, of the Optional Protocol, the State party shall give due consideration to the views of the Committee, together with its recommendations, and shall submit to the Committee, within six months, a written response, including any information on any action taken in the light of the views and recommendations of the Committee. The State party is also requested to publish the Committee's views and recommendations and to have them widely distributed in order to reach all relevant sectors of society. 